\title{
LEXICON
}

VOLUME 4

\section{THE CASE OF THE SIDEKICK: \\ THE ROLES OF DR. JOHN WATSON IN SHERLOCK HOLMES CANON BY SIR ARTHUR CONAN DOYLE}

\author{
Adiba Qonita Zahroh
}

\begin{abstract}
A sidekick in literature is perceived as a supporter of a hero or a man-behind a hero. However, it does not always work that way. In Sherlock Holmes canon, there can be found a well-known dr. John Watson who acts differently as a sidekick for Sherlock Holmes as a protagonist of the stories. Throughout the canon, Watson does not merely act as a supporter or a man-behind who just follows Holmes's moves. In many occasions, Watson contributes varied significant things in supporting Holmes through some roles he possesses. Moreover, what Watson contributes is found out to be influential to Holmes. Therefore, it can be seen that being a sidekick can do other things apart from following the hero all the time.

Based on the facts about Watson's contributions, this paper is conducted to examine the roles dr. John Watson as a sidekick. The data used in the research are 56 short stories and four novels of Sherlock Holmes bundled together in Sherlock Holmes canon. The method of collecting the data is executed through intensive reading, mapping out the roles of dr. John Watson found during the reading process, and analysing the collected data.

Since the focus of this paper is about dr. John Watson's roles and their influences towards Sherlock Holmes, objective theory is chosen to be employed. Related to the theory, this paper offers the explanation of intrinsic elements with focus on character element and sidekick character.
\end{abstract}

Keywords: Sidekick, dr. John Watson, Sherlock Holmes, Conan Doyle

\section{Intisari}

Sidekick atau teman karib di dalam dunia sastra dipandang sebagai pendukung pemeran utama atau orang yang berada di belakang pemeran utama. Akan tetapi, hal ini tidak selalu terjadi. Dalam canon Sherlock Holmes, terdapat dr. John Watson yang memiliki peran berbeda sebagai seorang sidekick bagi Sherlock Holmes, pemeran utama di dalam cerita. Di sepanjang canon, Watson tidak hanya berperan sebagai pengikut Holmes. Di berbagai kesempatan, Watson mengontribusikan berbagai macam hal penting dalam mendukung Holmes melalui peranan yang dia miliki. Terlebih lagi, hal-hal yang dilakukan Watson sangat berpengaruh kepada Holmes. Sehingga, dapat dilihat bahwa seorang sidekick dapat mengontribusikan hal-hal lain selain menjadi pengikut setia seorang pemeran utama.

Berdasarkan fakta yang berkaitan dengan kontribusi Watson, penelitian ini dilakukan untuk menelaah perananperanan Watson sebagai seorang sidekick. Data yang digunakan untuk penelitian adalah 56 buah cerita pendek dan empat buah novel Sherlock Holmes yang disatukan dalam satu bundel buku Sherlock Holmes canon. Metode penelitian dilakukan melalui membaca secara intensif semua cerita Sherlock Holmes, pemetaan peranan-peranan Watson, dan analisis data-data yang telah terkumpul.

Dikarekan fokus penilitian ini adalah peranan-peranan dr. John Watson dan pengaruhnya terhadap Sherlock Holmes, maka teori objektiflah yang dipakai dalam penelitian ini. Terkait dengan teori yang dipakai, penilitian ini menyajikan penjelasan tentang elemen-elemen intrinsik yang berfokus pada elemen karakter dan karakter sidekick.

Kata kunci: Sidekick, dr. John Watson, Sherlock Holmes, Conan Doyle 


\section{INTRODUCTION}

Sherlock Holmes is a fictional detective created by a Scottish doctor and writer, Sir Arthur Conan Doyle. Doyle successfully made him reach the popularity among the audiences until today and moved aside his predecessor of detective fiction authors.

In analysing the canon, present writer is very interested in examining characters in the canon itself; as characters in a literary work hold significant roles. Characters can evoke feelings of curiosity, fascination, like, love, dislike, hate, and affection, inside the audiences' heart.

In the canon of the story, there are two main characters who always appear in every story; they are Sherlock Holmes himself and his loyal sidekick, dr. John Watson. It is not always Sherlock Holmes, as the hero, who possesses significant roles in the stories. $\mathrm{dr}$. John Watson, as Holmes's sidekick also has important roles. According to Philips and Huntley (2001: 28), sidekick is the faithful supporter. Its role is to be faithful to someone or something regardless the attached one is protagonist or antagonist.

For the present writer, analysing the roles of $\mathrm{dr}$. John Watson as a sidekick or a man-behind is very interesting, since some analyses on the roles of $\mathrm{dr}$ John Watson and their significances towards Sherlock Holmes are very rarely conducted.

In bringing $\mathrm{dr}$. John Watson to the surface as the main topic for discussion in this paper, the present writer comes up with two objectives as follows:

a. To find out the roles performed by dr. John Watson thoughout Sherlock Holmes canon by Sir Arthur Conan Doyle.

b. To find out how the roles of dr. John Watson influence Sherlock Holmes' development thoughout Sherlock Holmes canon by Sir Arthur Conan Doyle.

Related to the objectives of this paper, the focus of examination is going to be the roles of dr. John Watson and their influences in Sherlock Holmes canon, which consists of 4 novels and 56 short stories. The present writer takes all stories in the canon to allow her to cover all roles performed by dr. John Watson and the roles impacts to Sherlock Holmes's development.

The analysis of this paper is going to be limited only to an intrinsic element, which is the character element. Thus, the present writer applies Abrams's objective theory from his book entitled The Mirror and the Lamp (1953) as the framework. The theory is also well-known as intrinsic approach since the primary focus of the method is on the intrinsic elements, like what Abrams argues in his book that "the objective orientation" which on principle regards the work of art in isolation from all these external points of reference, analyses it as self-sufficient entity constituted by its part in their internal relation, and sets out to judge it solely by criteria intrinsic to its own mode of being (26).

To clarify the concept of character described in objective theory, the present writer employs a concept of archetypal characters obtained from a book entitled Dramatica (2001) by Philips and Huntley and a concept of sidekick from a journal entitled "Side by Side": The Role of Sidekick (2003) by Ron Buchanan.

According to Philips and Huntley, there are eight archetypal characters, such as protagonist, antagonist, reason, emotion, sidekick, skeptic, guardian, and contagonist. However, from eight archetypal characters in total, the present writer just picks one of them, which is sidekick.

From some papers which have been reviewed before, the present writer found two papers discussing about dr. John Watson, which are The Formula of Classical Detective in Five Conan Doyle's Sherlock Holmes Stories by Sinatrya Haryo Wicaksono (2015) and Sherlock Holmes and Hercule: Analysation, Similarities, and Differences by Rósa Björk Blöndal (2014). However, both papers do not present the identification of dr. John Watson's roles in a deeper way. The Formula of Classical Detective in Five Conan Doyle's Sherlock Holmes Stories, Wicaksono only stresses Watson's roles as a biographer as a tool to support his explaination about the formula of classical detective, while the other roles are not discussed. In Sherlock Holmes and Hercule: Analysation, Similarities, and Differences, Blöndal only presents a broad description about Watson and she does not focuses on Watson's roles and the roles influences.

On the other hand, this paper is definitely different from other previous papers. It deals with the intrinsic elements, with focus on the roles of sidekick character in Sherlock Holmes canon who is dr. John Watson. Objective approach is applied in this present paper to accomplish a deeper discussion of some possible roles of dr. John Watson as a sidekick in the stories and the influences of his roles towards Sherlock Holmes's development and to prove that a sidekick can hold significant influences in a story. 


\section{ANALYSIS: THE CASE OF THE SIDEKICK}

\section{The Acquaintance: How It All Begins}

In this chapter, the present writer is going to discuss how both Sherlock Holmes and dr. John Watson meets. The two young man, Sherlock Holmes and dr. John Watson, who are still in their late 20s at that time, meet at the laboratory of Bartholomew Hospital from a mutual friend, named Stamford. At that time, in 1881, both Holmes and Watson are poor enough that they need a roomate to pay a flat.

Watson, who used to be an army doctor serving in Afghanistan, is retired because of his injury during the war. He has neither relatives nor family members since his last family member, that is his brother, has died. Moreover, he is not employed yet; that is why he needs a roomate to share the boarding bill. Besides, Watson says that "[he] should prefer having a partner to being alone" (Doyle, A Study in Scarlet: 8) in his lonely life.

Before Watson meets Holmes, Stamford warns Watson that Holmes is a strange person with whom Watson maybe does not want to spend the rest of his life. Stamford mentions that,

"[Holmes] is not a man that it is easy to draw out,... Holmes is a little too scientific for [Stamford's] tastes-it approaches to cold-bloodedness. [Stamford] could imagine [Holmes's] giving a friend a little pinch of the latest vegetable alkaloid, not out of malevolence... but simply out of a spirit of inquiry in order to have an accurate idea of the effects. To do him justice, [Stamford] think[s] that [Holmes] would take it himself with the same readiness. He appears to have a passion for definite and exact knowledge" (8).

Soon, as they live together in the flat, Watson wants to know more about Holmes and begins wondering about the man he has moved in with. Without having anything done in particular, Watson conducts a little investigation on what kind of person Holmes really is and what actually he is doing.

To figure out what Holmes is doing, Watson makes a list of Holmes's knowlegde which Holmes tells that they are very helpful for supporting his work.

1. Knowledge of Literature.-Nil.

2. Philosophy.-Nil.

3. Astronomy.-Nil.

4. Politics.-Feeble.
5. Botany.-Variable. Well up in belladonna, opium, and poisons generally. Knows nothing of practical gardening.

6. Geology.-Practical, but limited. Tells at a glance different soils from each other. After walks has shown me splashes upon his trousers, and told me by their colour and consistence in what part of London he had received them.

7. Chemistry.-Profound.

8. Anatomy.-Accurate, but unsystematic.

9. Sensational Literature--Immense. He appears to know every detail of every horror perpetrated in the century.

10. Plays the violin well.

11. Is an expert singlestick player, boxer, and swordsman.

12. Has a good practical knowledge of British law. (Doyle, A Study in Scarlet: 11-12).

When he finishes with the list, Watson is confused with the connection between those knowledge and Holmes's job that he ends up throwing it to the fire. Finally, he, patiently, waits until Holmes wants to share about it by himself because he believes that Holmes "ha[s] some strong reason for not alluding to it" (12). Related to what Watson does, he shows his politeness towards Holmes, and he tries to understand Holmes's nature as a person who is difficult to be drawn out, like what Stamford has told him before he meets Holmes.

After some times living with Holmes, Watson finally figures out what Holmes actually does. He conducts his own career as a consultant detective. Holmes's job as a consultant detective gives some meaningful impact to Watson. His instinct of being an army doctor is triggered. Something like what he used to face in a war, dead bodies, crimes, and danger all appear in his mind. From then on, wherever Holmes goes out to solve cases, Watson comes along.

Throughout his association with Holmes, Watson does not only act as a colleague to Sherlock Holmes. Based on a statement argued by Buchanan, Watson, as a sidekick, acts as a bestfriend and a narrator or a biographer. However, considering that Watson is a doctor, it adds lists in Watson's roles as a sidekick. In the following sub chapters, the present writer is going to examine four roles which are embodied by Watson, that is a bestfriend, a narrator or a biographer, a colleague, and a doctor, and the influences of Watson's roles to Sherlock Holmes's development. 


\section{dr. John Watson: How He Becomes a Sidekick}

Based on the concept of archetypal character, the present writer discovers that dr. John Watson embodies the characteristic of an archetypal character, which is a sidekick character. Like other sidekicks in other literary works, Watson has two characteristics pertaining in two motivations. His first motivation is depicted by being a faithful supporter and the second is by keeping his faith to the archetypal character he is attached to, in this case, Sherlock Holmes as the protagonist. By being faithful all the time, Watson can also be considered as a flat character. Readers can only see one side of him, that is being faithful to Holmes everywhere and anytime.

In his journal, Buchanan argued that a sidekick has at least three roles, which are as a narrator or biographer, a colleague, and a best friend. However, considering that dr. John Watson is also a doctor, the present writer thinks that a role as a doctor is needed to be added into the analysis. Through these roles, as Buchanan argues, a sidekick holds important roles that audiences need sidekicks more than they need heroes (24-25).

Therefore, in this sub chapter, the present writer is going to explain the significances of dr. John Watson as a sidekick through two characteristics which are seen in the four roles stuck to him as a narrator or biographer, a colleague, a best friend, and a doctor.

\section{a. dr. John Waston is A Bestfriend}

It is not always the case, that a man who is lack in ability to socialise cannot be befriended or cannot befriend someone else. Sherlock Holmes and dr. John Watson's relationship offers another unique perspective of friendship. Holmes with his "deficient in human sympathy..., his aversion to women, and his disinclination to form new friendships" (Doyle, The Greek Interpreter: 379), treats Watson not with the same respect as Watson treats him, somewhat in frivolous manner. Holmes makes fun of it and answers Watson's affection for his own enjoyment. When Watson's genuine faith, admiration, and loyalty are not answered equally by Holmes, it seems like Holmes and Watson's relationship is a kind of one-sided friendship.

The most frivolous manner is depicted in The Adventure of the Speckled Band, Holmes tells Watson to sit beside him in a dark room without giving any reason for why they do so. Watson with all his faithfulness, fulfills Holmes's request. All Watson does is later revealed that both of them are still luring a snake out from its hiding spot. Although, Holmes can manage the situation well when the snake is about to slither towards them, still, it is Holmes, somewhat, uses Watson's faithfulness only for his needs. Despite a dangerous situation Holmes brings to him, as a sidekick, Watson does not mind to keep accompanying Holmes in every case Holmes takes as a proof of his faithfulness towards Holmes.

In his early years, Holmes tends to spend his leisure time in his room doing what he loves without involving anybody else and only has one friend and one acquaintance (based on The Musgrave Ritual and The "Gloria Scott"). However, after he meets and befriends Watson, it is such an extraordinary stuff. Gradually, Holmes undergoes some changes in his traits that are going to be discussed in the following discussions.

Since he is retired as an army doctor, he has accustomed to face such violences, dead bodies, and other murderous things, so when Holmes invites him to investigate crimes, it does not give any shock effects for Watson. Not only regarding to the mental readiness, his hard time as a person who has ever served in a war and his atheletic body helps him to survive while he is accompanying Holmes solving cases which need extra energy to work and think fast in any situation. Watson, while accompanying Holmes in solving cases, feels a certain pleasure, which indicates that their relationship base is now changing into the pleasurebased relationship (which will be discussed deeper in the part of "Doctor John Watson is A Colleague").

In this relationship, it can be seen that closest friends are the persons who can complement each other. Like Holmes says in The Hound of Baskervilles, he praises Watson for being the conductor of light for him.

It may be that you are not yourself luminous, but that you are a conductor of light. Some people without possessing genius have a remarkable power of stimulating it. I confess my dear fellow, that I am very much in your debt (591).

In their early acquaintance, when they have a conversation about Holmes's job as a consultant detective, "[Watson's] respect for [Holmes's] powers of analysis increased wondrously" (Doyle, A Study in Scarlet:14). Holmes adds that he is very bored for there is no interesting case can challenge his brain. Then not long after his complaint, Holmes gets a case about a murder in Lauriston Garden. Watson becomes the most hearty party, while Holmes is still not in mood in 
taking the case since he has to cooperate with Inspector Gregson and Lestrade from Scotland Yard. "I [Watson] was amazed at the calm way in which he rippled on. 'Surely there is not a moment to be lost," I cried, "shall I go and order you a cab?" (15). In their early acquaintance, Watson already shows his supporting attitude to Holmes by willing to order Holmes a cab so that Holmes can have a case to do even he has to deal with unpleasant colleague from Scotland Yard. This attitude of supporting shows how Watson performs his character as a sidekick. Holmes, then, is ready to take the case and asks Watson to come with him. Without any objections, Watson accepts Holmes's offer. With his supporting attitude towards Holmes, Watson gives something new into Holmes's world. Holmes who is usually lives alone and surely he maintains everything alone, now he has a friend who cares with him.

It can be found in the canon itself that Holmes and Waston's friendship is very lovely. It is sometimes shown in the way how Holmes comfort Watson after he makes Watson angry, like what happens in The Hound of Baskerville. At that time, Watson has been working to investigate the case and composes reports from them with full of pain and pride. However, then, he finds out that his existence is just to distract the villain's attention. Watson feels that Holmes has used him only as a distraction and he gets angry to Holmes.

'Then my reports have all been wasted!'-My voice trembled as I recalled the pains and the pride with which I had composed them.

Holmes took a bundle of papers from his pocket.

'Here are your reports, my dear fellow, and very well thumbed, I assure you. I made excellent arrangements, and they are only delayed one day upon their way. I must compliment you exceedingly upon the zeal and the intelligence which you have shown over an extraordinarily difficult case' (Doyle, The Hound of Baskerville: 644).

From the conversation above, Holmes tries to calm Watson down by showing Watson's reports to assure his effort is not in vain. Holmes also adds some compliments for what Watson has done in coping with such an extraordinary difficult case. In this scene, the present writer can assure that Holmes has obtained appreciation towards Watson, that he does not want to disappoint his friend. In this stage, Holmes undergoes some changes in his traits shown in how he treats
Watson and also his willingness to talk about his personal life, about his brother Mycroft to Watson.

There is an event in The Three Garridebs, when Watson is attacked by a villain. When the villain is cornered, he pulls his gun and shoots Watson. Without any hesitation, Holmes, who is knowing this incident, knocks out the villain and tuns to Watson directly to see that Watson is not injured.

'You're not hurt, Watson? For God's sake, say that you are not hurt!

It was worth a wound-it was worth many wounds-to know the depth of loyalty and love which lay behind that cold mask. The clear, hard eyes were dimmed for a moment, and the firm lips were shaking. For the one and only time I caught a glimpse of a great heart as well as of a great brain. All my years of humble but single-minded service culminated in that moment of revelation.

'It's nothing, Holmes. It's a mere scratch.'(923)

After knowing that the wound is not serious, Holmes is visibly relieved, but still he turns towards the villain and threats him. "By the Lord, it is as well for you. If you had killed Watson, you would not have got out of this room alive..." (932). If Holmes works professionally as a detective, he will not be so emotional when he puts Watson in danger. However, Holmes places Watson as his bestfriend so that he feels regretful and panic when Watson is in danger. It makes Holmes alert to make sure that Watson is in the safer area (A more detailed explaination is going to be presented in "Doctor John Watson is A Colleague). From those traits, Watson is touched by Holmes's sincere kindness and through his description in The Final Problem, Watson calls Holmes simply "as the best and the wisest man whom [he has] ever known" (417).

It is, indeed, different, how Holmes treats the world and how Holmes treats Watson. As a sidekick, Watson has clearly given influences towards Holmes.

In this case, as a bestfriend, Watson has similarities with Holmes's old friend, Victor Trevor. Both of them are hearty, do not have many friends, and have something in common with Holmes. Watson also offers a comfortable sense for Holmes through their friendship that he can change Holmes from an unavailable person into an available one who can tell story about himself and share his life with another people for a long time. Another important influence of Watson is that with his care, Watson can make Holmes 
to be a warmer and more thoughtful person. Watson, as his bestfriend who is with Holmes almost everyday, can see the true Holmes since Holmes has revealed himself being much more than heartless machine man.

\section{b. dr. John Watson is A Narrator and Biographer}

Before Holmes meets Watson, his detective practice is not well known. Because of that, Holmes is facing financial difficulties and he needs a flatmate to share the rent. Even his numerous contributions in helping Scotland Yarders solve cases cannot tell the whole public that he is a great detective.

Watson, as a devoted biographer, is the one who makes Holmes being recognised by the public. Holmes praises Waston as "[a] biographer [who] had come to glorify me [Holmes]" (Doyle, The Musgrave Ritual: 333). Being fascinated with Holmes's genius deduction skill and his remarkable ability in solving cases, Watson is willing to record the adventure stories about Holmes through his writings. This action clearly shows Watson's support on Holmes's career in detective practice. And it shows how Watson acts as a sidekick to Holmes. In A Study in Scarlet, Watson shows his willingness in devoting himself for being Holmes's biographer, that he exclaims, "'It is wonderful!' [Watson] cried. 'Your merits should be publicly recognised. You should publish an account of the case. If you won't, I will for you'" (67).

Since then, the name of Sherlock Holmes is in the air that almost everybody knows him. His adventure stories are popular among many people. It gives a positive impact on Holmes's detective practice. It results many people from the highest social class until the lowest, who want their problems to be solved, come to his flat to consult. No more financial issues that should be dealt with. Through what Watson does as a narrator and biographer to Holmes, Watson shows the characteristic as a sidekick character, that is supporting. In this case, he supports Holmes in increasing Holmes's detective practice condition and financial state.

However, if Watson expects gratitudes or compliments from Holmes over his hard work on writing a biography for Holmes, it will be very regretful. Since, still in The Study in Scarlet, Holmes critises on Watson's ability in telling stories about his adventure, especially delivering Holmes's method of solving cases. Holmes thinks that Watson is lacking in ability of describing his scientific method during the case solving. He says that Watson should write in cold and unemotional way since Watson is writing about scientific detections. In Holmes's mind, if Watson keeps employing his old style, the stories will give the same effect when the readers read a love story or "an elopement into the fifth proposition of Euclid" (12).

Understanding that he is underestimated by Holmes's irrating literary critism, Watson challenges Holmes to write his own memoir, even he keeps his activity in writing Holmes's stories no matter what Holmes says about his narration style. Once again, Watson proves himself as a sidekick to Holmes by showing his faithfulness in writing Holmes's stories even after Holmes's mockery comment on his narration style.

Years later, when Holmes is no longer living with Watson and leaves London to his retirement dwelling in Sussex near the beach, he has to write his memoir by himself. When it comes to the time when Holmes takes the challenge, to the big surprise, he feels that his writing results, which are The Adventure of the Lion's Mane and The Blanced Soldier, are not as pleasureable as the stories Watson has written all this time. He also says that he has to struggle to produce those stories. In this stage, Holmes shows his dependence towards Watson as his biographer and narrator that he needs Watson to write his adventures again like it used to be. Moreover, Holmes also shows that he does not feel confident with himself since he keeps comparing his own writing to Watson's. Watson's existence in Holmes's life has changed Holmes from an independent person into a less independent one, and from a confident person into less confident one.

In telling the stories, Watson can be very cautious. There are some cases which involve sensitive issues, for instance regarding with the dates, places and even the clients and other people involved, especially honorable clients with certain images that has to be maintained. In order to keep clients' privacy so that his stories can be published safely, sometimes, Watson has to conceal or fugde clients' identities, the places where the cases occur, and also the time when the cases happen. If Watson reveals them, even vaguely, it can suffer Holmes's detective practice because the secrets will be easily sniffed by the readers of the canon, by tracking the date and places of the cases. Holmes may loss his prospective clients because the clients will hesitate to employ him.

Once, there is a client who is really worried if his true identity is revealed and does not want to tell Holmes his real name, like in a case entitled The 
Illustrious Client. It is a case of an illustrious client whose a daughter insists to marry a man who pretends to love her. The problem is that the man never treats any women in a proper way and has ever killed his previous wife, but the daughter does not want to take anybody's advice to cancel the marriage. The daughter believes that the man is a good person while everybody around is evil. She thinks that people just want to separate her from the man by accusing him for doing any ruthless deeds.

Too worry that his identity will be revealed, the illustrious client sends his trusted as his intermediary. In this case, Holmes and Watson have to face an intermediary who is presistent not to mention the true identity of the illustrious client, because the intermediary thinks that this case can hurt his client's dignity. Holmes insists the intermediary to reveal his client's identity so that Holmes will not confuse himself in digesting the case for "...[Holmes is] accustomed to have mystery at one end of [his] cases" (Doyle, The Illustrious Client: 862). However, with his prowes, Holmes can identify the real identity of the client, and Watson also knows about it, by himself, at the end of the story. However, Holmes asked Watson not to mention his name, "Let that now and forever be enough for us" (Doyle, The Illustrious Client: 871).

Related to this issue, there is a possibility that Watson may also conceals Holmes and his true identities, includes everbody who are close to them, like Mrs. Hudson who is their landlady, Mycroft Holmes who is Holmes's smarter brother, and Inspector Lestrade who is one of the Scotland Yarders. They believe that if Watson keeps their own identities unveiled, people around them will find the identities of the clients and other sensitive issues easily even if Watson presents them anonymously (Klinger, Leslie.S: 7).

Beside protecting clients' secret issues and Holmes's detective practice at the same time, Watson also presents each stories in very interesting way, like what Holmes says, Watson "makes of so wonderful a happening and of [Holmes's] eventual triumph against every difficulty" (Doyle, The Adventure of the Lion's Mane: 953). At the initial part of each story, instead of presenting the problems, Watson introduces Holmes to the readers by showing a domestic and peaceful scene of Holmes and himself having breakfast, sitting in the sofa, or just drinking their tea in their flat room on 221B Baker Street. During those circumstances, sometimes, Holmes magically can predict that there will be a client comes into their room and Holmes also adds detail descriptions of the client's correctly. By displaying Holmes's special prowes in the exposition, Watson wants to build up Holmes's image to his readers as a great detective that no matter how big, baffling, and dangerous the cases are, Holmes will be able to overcome them.

From all cases which Holmes has ever taken, three of them are failures. Holmes says that he has ever been defeated three times, two times by men and one time by a woman. Despite of a large number of the cases, Watson does not publish all stories of Sherlock Holmes, he only chooses the most interesting ones. Once, Holmes asks Watson to publish some stories which contains his failures in solving cases, but Watson refuses it. However, there is a published story entitled $A$ Scandal in Bohemia which tells Holmes's failure against a woman named Irene Adler, whom later becomes the only woman Holmes adores and respects. Defeated by a woman is a new interesting experience to Holmes, since he has never defeated by a woman's wit before. Irene Adler, according to Holmes, is such an exceptional woman who "...eclipes and predominates the whole of her sex" (Doyle, A Scandal in Bohemia: 125).

Watson's refusal in publishing other stories which include Holmes's failures indicates that Watson does not want to hurt Holmes's image as a great detective. While, the publication of A Scandal in Bohemia, which is a story of Holmes's failure in solving a case, is a distinctive story. It is because it mostly tells about a woman, Irene Adler, and her high occupation. Moreover, it also deals with Holmes's admiration towards her, which is very unusual since Holmes has seldom be attracted by women, "...for [his] brain has always governed [his heart]." (Doyle, The Adventures of Lion Mane: 956)

In making The Great Detective even greater, Watson uses his own perspective with peripheral first point of view as his tool to elaborate the sequences of an investigation conducted by Sherlock Holmes. In this case, he knows Holmes's outward, like what Holmes is doing, but he does not know what Holmes's inward, like what Holmes is thinking. It makes why Watson always shows his bewilderment during the investigation.

However, his bewilderment becomes a good point in his writing style. Through his bewilderment, Watson can keep the denoument of the case as a secret until the last pages and trigger readers' curiosity and put more tension in his stories. Moreover, it can allow Watson to direct his readers's attention into the wrong path, and preventing them from solving the mystery in the front 
pages. Beside that, Watson's bewilderment implies that the case is really unsolvable.

Here, it can be seen that Watson's role as a narrator is very crucial. As a sidekick, Watson does not merely act as a supporter and a follower to Holmes as a hero. In contrary, Watson is a sidekick with an ultimate authority in determining how stories should be received and how Holmes should be appreciated by the readers. In this case, Watson is the creator. The grandeur of Holmes's cases is created by Watson by using his method in story-telling to make the cases seem unsolvable. By making those cases seem unsolvable, Watson tries to shows that those unsolvable cases can only be solved by Holmes not by other people, even by constables from Scotland Yard.

From his role as a narrator and biographer, Watson has put his influences on Holmes's life. Through his stories, he becomes a producer for Holmes. He introduces who Holmes is and what Holmes can do to the world. This attempt changes Holmes's financial and image conditions. Holmes becomes famous due to the publication of the adventure stories of himself. Along with that, his image, detective practice, and clients grows really well which leads Holmes into a more comfortable finanacial condition. Later, the growth of his image also leads Holmes to be a less independent person. Holmes tends to be dependent to Watson and his image which Watson has build for him.

\section{c. dr. John Watson as a colleague}

"This is my friend and colleague, Dr. Watson...." (Doyle, A Scandal in Bohemia: 127) is a statement delivered by Holmes when he introduces Watson to his clients before the clients tells their problems. In $A$ Scandal in Bohemia, when Sherlock Holmes's client, the king of Bohemia, feels hesitate with Watson's existance that he will not tell his story in front of Watson, Holmes tries to convince the king that it is alright if he tells his story in front of Watson, since Watson is his colleague. Holmes also adds that he will not take the king's case unless Watson can stay and hear the story.

Throughout the canon, Watson always plays a good role as a colleague, he can be considered as an assistant detective for Holmes. He is a well-build man and he also knows how to do some strategy when encountering dangers since he used to be an army doctor. He knows what to do in any situation given, although, indeed his intelligence is not as outstanding as Holmes's, but still he is clever. Once, in The Crooked Man, Watson expresses his excitement in doing investigation with
Holmes that "I [Watson] was myself tingling with that half-sporting, half-intellectual pleasure which I invariably experienced when I associated myself with him [Holmes] in his investigations" (362). By always being there for Holmes to assist the variously dangerous investigations, Watson shows both a sidekick's characteristics as a supporting and faithful character to Holmes as a protagonist he is attached to.

Moreover, Holmes's trust in Watson is undoubted. When Holmes is still investigating more dangerous case, Holmes asks Watson to assist him to manage the other less dangerous case. It does not mean that Holmes does not believe in Watson to handle the bigger case, but Holmes intends put Watson in a safer area, since he is worried for Watson's safety. By giving Watson a responsibility to investigate some cases, Holmes, clearly, considers Watson as someone who can be relied. Although it is less dangerous, the case Watson takes charge is still a dangerous case.

The event can be seen in The Hound of Baskervilles when Watson is asked to accompany Sir Henry Baskerville to stay in the Baskerville Hall in Devonshire. The Baskerville Hall is an isolated place near a moor where Sir Charles Baskerville, Sir Henry's uncle, has just been killed. Rumour has it, he is killed by a gigantic mystical hound. Watson has to be a companion for the last Baskerville heir for some days while Holmes is investigating the case secretly, without Watson's consent. Holmes, in the first place, has sniffed something unusual behind the mystery of the gigantic hound, and he thinks the death of Sir Baskervilles is not caused by anything related to the myth, but simply done by human. With this reason, Holmes asks Watson to accompany Sir Henry Baskerville. Thus, it is revealed clearly that Watson is not doing an easy job. His duty is not just accompany Sir Henry Baskerville but also has to protect him and guarantee his safety. It proves that Watson plays a very crucial role during the investigation process.

Watson does his job perfectly successful by being Holmes's eyes and ears, during doing his duty, since Watson is asked to send regular letter to Holmes containing the situation around Baskerville Hall. He finds some suspects, such as Mr., Mrs. Barrymore, and Laura Lyons. Doing his best to clarify the mysterious threads in that isolated place without Holmes, Watson discovers that both the suspects do not have anything to do with Sir Charles's death.

Other than that, Watson discovers that the lonely figure surveying the moor is none other than Sherlock 
Holmes himself. In this stage, it can be seen that Holmes conducts an investigation in more dangerous area than Watson. Holmes puts himself out of the domestic and secure place, like in the moor.

Later, Watson finds out that all this time, Holmes actually does his own investigation on the Baskerville case without Watson's knowledge. Knowing this, Watson gets angry since he feels je has been used by Holmes and Holmes immediately comforts him by convincing that what he has done in Dartmoor is a great result of work. Looking from a colleague's perspective, Holmes's attitudes in comforting Watson and involving him in a case are a manifestation of appreciation which Holmes never gives before to his other colleagues, like to any constables from Scotland Yard. Then, Holmes adds some explaination to Watson that he intentionally does a secret investigation in order not to catch up the villan's attention related to his involvement in solving the mystery.

By participating in helping Holmes to conduct investigation, Watson has proven to the readers that he contribute many in Baskervilles's case as a colleague of Sherlock Holmes. In addition, Watson also proves that as a sidekick, he has put some influences into Holmes that Holmes now learns how to appreciate other's work result.

\section{d. dr. John Watson as a doctor}

Although he is a doctor and starts a medical practice, it seems he never really works on it. When Holmes asks Watson to accompany him travelling in means of solving cases, Watson is willing to leave his medical practice and asks his neighbour doctor to see his patients instead. This situation illustrates Watson's faithfulness and support towards Holmes as a sidekick that he puts his deep concern towards Holmes. In The Red-Headed League, Watson reveals that "[his] practice is never really absorbing" (144). Moreover, when he leaves his practice to accompany Holmes, his wife never extends any objections.

Holmes has a bad habit which Watson really hates. When Holmes has some cases to solve, he forgets to eat, even to sleep. Moreover, it often happens for days. Holmes says that when his brain is working, nothing should interupts it. However, Watson, as a doctor, worries about his friend's bad habit that he keeps grumbling about health in front of Holmes, hoping his friend will take his suggestion to eat and take a little rest to maintain his health. How hard Watson tries,
Holmes never reckons Watson's discourse; he is just ignoring him as usual.

Another thing that Watson worries about Holmes is his habit consuming cocaine regularly and for a long time whenever he does not have any cases to do. Holmes's alleged addiction is first mentioned by Watson in The Sign of the Four which is set in 1897. Watson sees Holmes give him himself cocaine injection which he called a seven-per-cent solution. He adds that he is irritated to witness that performance which Holmes has been doing for "three times a day for many months" (67).

Throughout the canon, Watson only mentions four times about Holmes's bad habit in concaine which are in The Sign of the Four (1890), A Scandal in Bohemia (1891), The Yellow Face (1893), and the last is in The Missing Three-Quarter (1904) when Watson mentions he has weaned Holmes from consuming drug. His act of weaning Holmes from consuming drug has proved that Watson, as a sidekick to Holmes, supports Holmes's healthy condition and in another stage Watson shows his faithfulness in Holmes by willing to wean Holmes to discontinue his drug habit no matter how Holmes reacts to it.

\section{CONCLUSION}

From several roles discussed in previous chapters, dr. John Watson has put his influences toward Sherlock Holmes. As a sidekick, Watson plays some important roles in the life of Sherlock Holmes. As a sidekick, Watson does not merely play as a follower or as a manbehind to Sherlock Holmes as a protagonist. Watson's roles are very crucial and exceptional. With his roles as a bestfriend, a narrator or biographer, a colleague, and a doctor, Watson can give influences to Holmes's life, especially his role as a narrator and a biographer. This role determines how stories should be received and how Holmes's image should be appreciated by the readers. This role puts Watson as a creator. What it is more, it also gives effects on Holmes himself internally that in his later years, he becomes more dependent to Watson's presence and narrative style, and the image of Holmes himself which Watson builds for him.

To summarise the founding of this paper, the presernt writer provides a table, in Appendix, which presents the summary of Sherlock Holmes's development influenced by dr. John Watson's roles as a sidekick. 


\section{BIBLIOGRAPHY}

Abrams, M. H. 1976. The Lamp and the Mirror. New York: Oxford University Press. Print.

Buchanan, Ron. 2003. "'Side by Side': The Role of the Sidekick," Studies in Popular Culture, 26(1): 1526. JSTOR. PDF File. Accessed on October 17th, 2014. http://www.jstor.org/stable/23414984

Doyle, Arthur Conan. The Complete Sherlock Holmes. PDF File. Accessed on September 1st, 2011. $\leq$ https://sherlock-holm.es/stories/pdf/a4/1-sided/ cano.pdf $>$
Klinger, Leslie. S. "What do We Really Know about Sherlock Holmes and John H. Watson?," Baker Street Journal, 54(3): 6-15. PDF File. Accessed on September 9th, 2014.

Philips, Melanie Anne and Chris Huntley. 2001. Dramatica: A New Theory of Story. California: Screenplay System Incorporated. Print.

\section{Appendix : Sherlock Holmes's Development Influenced by dr. John Watson's Roles as A Sidekick}

\begin{tabular}{|c|c|c|}
\hline Holmes & $\begin{array}{l}\text { Old Conditions and } \\
\text { Characeteristics }\end{array}$ & New Conditions and Characteristics \\
\hline As a bestfriend & \multirow{2}{*}{$\begin{array}{l}\text { Holmes is an anti-social } \\
\text { and unavailable person. }\end{array}$} & \multirow{2}{*}{$\begin{array}{l}\text { Holmes is more available and can feel comfortable with Watson's } \\
\text { presence that he is willing to share his private life to Watson. } \\
\text { He shows his emotions and pays more attention to Watson. }\end{array}$} \\
\hline $\begin{array}{l}\text { Watson understands Holmes's nature } \\
\text { which give Holmes the feeling of } \\
\text { comfortable. }\end{array}$ & & \\
\hline As a narrator/biographer & \multirow{2}{*}{$\begin{array}{l}\text { Holmes's detective practice } \\
\text { is not famous that he has to } \\
\text { face financial difficulties. }\end{array}$} & \multirow{2}{*}{$\begin{array}{l}\text { Holmes's detective practice is very famous, due to dr. John Watson's } \\
\text { writings about Sherlock Holmes's adventures. }\end{array}$} \\
\hline \multirow{2}{*}{$\begin{array}{l}\text { Watson manages to improve Holmes } \\
\text { and his financial conditions by writing } \\
\text { stories about Holmes's adventures. } \\
\text { Also with his writing, Watson shapes } \\
\text { Holmes's image and covers clients' } \\
\text { secret for the sake of Holmes's } \\
\text { detective practice. }\end{array}$} & & \\
\hline & $\begin{array}{l}\text { Holmes is indifferent with } \\
\text { any publications of his } \\
\text { detective career. }\end{array}$ & $\begin{array}{l}\text { When Holmes does not live with Watson anymore, he starts writing } \\
\text { his own adventures, even only two. However, Holmes does not feel } \\
\text { confident with his own writing and wants Watson writes the stories } \\
\text { for him. Holmes also does not feel free to write his stories with his } \\
\text { own scientific style and he tends to stick to Watson's writing style, } \\
\text { the more dramatic one. It is shown when he always compare his } \\
\text { writing with Watson's. }\end{array}$ \\
\hline As a colleague & \multirow{2}{*}{$\begin{array}{l}\text { Holmes underestimates his } \\
\text { colleagues (Scotland Yard). }\end{array}$} & \multirow{2}{*}{$\begin{array}{l}\text { Holmes is be able to appreciate his collague's work (dr. John } \\
\text { Watson). }\end{array}$} \\
\hline Watson acts as an assistant-detective. & & \\
\hline As a doctor & \multirow{2}{*}{$\begin{array}{l}\text { Holmes does not have } \\
\text { particular partner in } \\
\text { forensic investigation. }\end{array}$} & \multirow[t]{2}{*}{ Holmes has Watson as his partner in forensic investigation. } \\
\hline Watson helps Holmes in forensic by & & \\
\hline $\begin{array}{l}\text { applying his medical skill. Moreover, } \\
\text { he also acts as Holmes's doctor who } \\
\text { always concerns with Holmes's health. }\end{array}$ & $\begin{array}{l}\text { Holmes always consumes } \\
\text { cocaine to get rid of his } \\
\text { boredom. }\end{array}$ & $\begin{array}{l}\text { It is indicated that Holmes discontinues his habit in consuming } \\
\text { cocaine and chooses to do beekeeping to get rid of his boredom. }\end{array}$ \\
\hline
\end{tabular}

